\begin{tabular}{|c|c|c|}
\hline BIODIK & $\begin{array}{c}\text { BIODIK: Jurnal IImiah Pendidikan Biologi } \\
\text { ISSN 2580-0922 (online), ISSN 2460-2612 (print) } \\
\text { Volume 07, Nomor 04, Tahun 2021, Hal. 61-69 } \\
\text { Available online at: } \\
\text { https://online-journal.unja.ac.id/biodik }\end{array}$ & BIODIK \\
\hline
\end{tabular}

Research Article

OPEN ACCESS

\title{
Pengembangan Media Pembelajaran Protista Dan Fungi Melalui Bot Aplikasi Telegram
}

\section{(Development of Learning Media for Protists and Fungi through Telegram Application Bot)}

Nur Chusnul Chotimah Ratna Sari ${ }^{\star 1}$, Evi Roviati ${ }^{2}$

1Jurusan Biologi, FITK, Institut Agama Islam Negeri Syekh Nurjati Cirebon.

JI. Perjuangan, Sunyaragi, Kec. Kesambi, Kota Cirebon, Jawa Barat 45132

2Pusat Kajian Ekologi Pesisir Berbasis Kearifan Lokal, Jurusan Biologi Universitas Negeri Gorontalo.

JI. Perjuangan, Sunyaragi, Kec. Kesambi, Kota Cirebon, Jawa Barat 45132

*CorrespondingAuthors: : nurchusnul.crs@gmail.com, evi1roviati@gmail.com

\begin{tabular}{|c|c|}
\hline Informasi Artikel & ABSTRACT \\
\hline $\begin{array}{l}\text { Submit: } 16-12-2020 \\
\text { Diterima: } 03-11-2021 \\
\text { Dipublikasikan: } 17-12-2021\end{array}$ & $\begin{array}{l}\text { This study aims to develop virtual learning media using the telagram bot } \\
\text { application in learning biology of the functional protist material and the feasibility } \\
\text { of virtual learning media using the telegram bot application in learning. Students } \\
\text { have a high level of difficulty in understanding and describing the life cycle of } \\
\text { fungi. Based on this, a solution is needed that can help students and lecturers to } \\
\text { overcome the limitations of the object to be observed by presenting the media in } \\
\text { learning. Multimedia will stimulate some students 'sensory organs, so that } \\
\text { students' understanding of biology becomes more perfect. Compared to } \\
\text { conventional learning, m-learning allows more opportunities for ad hoc } \\
\text { collaboration and informal interaction among learners. This study uses a } \\
\text { Research and Development type of research (research and development) by } \\
\text { developing the DDD-Emodel, namely decide, design, develop and evaluate. The } \\
\text { research results obtained that, the assessment of the material results from all } \\
\text { aspects of the assessment for the validation of the telegram bot as a learning } \\
\text { medium is the result of the validation of the interactive multimedia learning } \\
\text { telegram bot, the biology of the protist function, in the presentation aspect, it is } \\
\text { obtained } 85 \% \text { with a very valid category.The overall media feasibility aspect has } \\
\text { a percentage of } 87,6 \% \text {. Thus the learning bot produced in this study can be } \\
\text { used as a reference in multimedia learning courses. } \\
\text { Key words: Learning Multimedia, Telegram Bot, Protiata Fungi }\end{array}$ \\
\hline Penerbit & ABSTRAK \\
\hline $\begin{array}{l}\text { Program Studi Pendidikan Biologi } \\
\text { FKIP Universitas Jambi, } \\
\text { Jambi- Indonesia }\end{array}$ & $\begin{array}{l}\text { Penelitian ini bertujuan untuk mengembangkan media pembelajaran virtual } \\
\text { dengan menggunakan aplikasi bot telagram dalam pembelajaran biologi materi } \\
\text { protista fungi dan kelayakan media pembelajaran virtual meggunakan aplikasi } \\
\text { bot telegram dalam pembelajaran. Siswa memiliki tingkat kesulitan yang tinggi } \\
\text { dalam memahami dan mendeskripsikan siklus hidup jamur. Berdasarkan hal } \\
\text { tersebut maka diperlukan suatu solusi yang dapat membantu mahasiswa dan } \\
\text { dosen dalam mengatasi keterbatasan objek yang akan diamati dengan } \\
\text { penyajian media dalam pembelajaran. Multimedia akan merangsang beberapa } \\
\text { organ sensorik siswa, sehingga pemahaman siswa terhadap biologi menjadi } \\
\text { lebih sempurna. Dibandingkan pembelajaran konvensional, m-learning } \\
\text { memungkinkan adanya lebih banyak kesempatan untuk kolaborasi secara ad } \\
\text { hoc dan berinteraksi secara Informal di antara pembelajar. Penelitian ini } \\
\text { menggunakan jenis penelitian Research and Development (penelitian dan } \\
\text { pengembangan) dengan pengembangan model DDD-E yaitu decide, design, } \\
\text { develop dan evaluate. Hasil penelitian yang diperoleh bahwa, penilaian hasil }\end{array}$ \\
\hline
\end{tabular}


materi dari keseluruhan aspek penilaian untuk validasi bot telegram sebagai media pembelajaran adalah Hasil validasi multimedia pembelajaran interaktif bot telegram materi biologi protist fungi pada aspek penyajian diperoleh $85 \%$ dengan kategori sangat valid Aspek kelayakan media secara keseluruhan meiliki presentase $87,6 \%$. Dengan demikian bot pembelajaran yang dihasilkan dalam penelitian ini dapat dimanfaatkan sebagai salah satu referensi dalam mata kuliah multimedia pembelajaran.

Kata kunci: Media, Multimedia Pembelajaran, Bot Telegram, Protiata Fungi

This BIODIK : Jurnal IImiah Pendidikan Biologi is licensed under a CC BY-NC-SA (Creative Commons Attribution-ShareAlike 4.0 International License)

\section{PENDAHULUAN}

Kemajuan teknologi di satu sisi terdapat efek negatif terhadap minat baca dan belajar seorang mahasiswa. Menurut Wibawa (2014) dalam jurnal "Students' Creative e-Portfolios: Using Android Cell Phone Cameras for Inventive Beauty Photography" didapatkan bahwa siswa lebih tertarik media pembelajaran kreatif, terbukti dari respon yang didapatkan respon rata-rata pada skala 3.31, dari total skala 5. Salah satu keuntungan dari teknologi smartphone yaitu sebagai media audio visual dapat membantu meningkatkan pemahaman siswa untuk menampilkan materi pembelajaran dalam bentuk video dengan lebih nyata. Dari fakta yang sering ditemui melalui potensi dan masalah menunjukkan bahwa masih banyak mahasiswa yang tidak menyukai belajar protista dan fungi dikarenakan akses informasi yang relatif sulit dicari.

Pengajar dituntut untuk lebih kreatif dalam menyampaikan materi-materi biologi khususnya pada protista dan fungi yang terkenal sulit dikalangan siswa, pengajar harus bisa terbuka dengan perkembangan zaman yang terus menerus berubah dan mampu menyerap dengan konsumen produkproduk hasil perkembangan teknologi dan komunikasi terbanyak. Hal ini dimanfaatkan oleh Setya Chendra Wibawa dalam penelitiannya yang berjudul "The Design And Implementation Of An Educational Multimedia Interactive Operation System Using Lectora Inspire" yang mana tujuan dari penelitian ini untuk menghasilkan alat dan praktik pembelajaran interaktif yang valid berdasarkan media pembelajaran Lectora Inspire. Dari penelitian tersebut digunakan untuk mengetahui respon siswa terhadap alat pembelajaran, dan mengetahui hasil belajar siswa setelah menggunakan media pembelajaran Lectora. Hasil dari penelitian tersebut membuktikan bahwa para siswa sangat puas dengan media pembelajaran tersebut dengan mencapai presestase $85.9 \%$ sedangkan presentase tingkat kelulusan mencapai 84.375\%.(Wibawa, 2014).

Media pembelajaran adalah alat yang berfungsi untuk menyampaikan pesan pembelajaran. Pembelajaran merupakan sebuah proses komunikasi antara peserta didik, pendidik, dan bahan ajar. Komunikasi tidak akan berjalan tanpa bantuan sarana penyampai pesan atau media (Simamora, 2009:65). Multimedia dapat digunakan untuk mengubah konsep abstrak menjadi lebih konkret, menampilkan objek seperti mikroorganisme yang tidak terlihat oleh manusia Mata, dan multimedia mampu mengatasi keterbatasan ruang, waktu dan tenaga dalam menampilkan proses yang kompleks, sehingga Biologi dapat diajarkan oleh guru dan dipahami oleh siswa dengan mudah. M-learning adalah pembelajaran yang unik karena pembelajar dapat mengakses materi, arahan dan aplikasi yang berkaitan dengan pembelajaran kapan-pun dan dimana-pun. Hal ini akan meningkatkan perhatian pada materi pembelajaran, membuat pembelajaran menjadi perpasif, dan dapat mendorong motivasi pembelajar kepada pembelajaran sepanjang hayat (lifelong learning). Selain itu, dibandingkan pembelajaran 
konvensional, mlearning memungkinkan adanya lebih banyak kesempatan untuk kolaborasi secara ad hoc dan berinteraksi secara Informal di antara pembelajar. (Tamimuddin, 2007).

Multimedia mampu membangun pengetahuan siswa secara aktif, bekerja dalam kelompok dan menggunakan multi indera. Multimedia memberikan kesempatan kepada siswa untuk dapat belajar dimanapun dan kapanpun (fleksibilitas) (Satyaprakasha, 2014). Telegram didirikan pada tahun 2013 oleh dua orang bersaudara yaitu Nikolai dan Pavel Durov yang bertujuan untuk menyediakan fungsi berkirim pesan yang aman bagi pengguna yang tidak mengerti teknologi. Telegram memungkinkan pengguna untuk mengirim pesan teks, pesan suara dan berkomunikasi dalam grup.(Saribekyan dan Margvelashvili,2017)

Telegram mesengger salah satu Social Mesenger yang penuh dengan fitur-fitur uniknya. Salah satunya adalah fitur bot-nya (Telegram Bot), dan dengan fitur open source dari Telegram Mesenger jadi kita serasa bebas melakukan apapun terhadap Telegram Mesenger. Telegram Bot API menawarkan platform untuk pengembang yang memungkinkan mereka untuk dengan mudah menangkan data sensor dan mengubahnya menjadi informasi yang berguna. Menggunakan platform Telegram Bot API untuk mengirim data ke awan dari perangkat berkemampuan Internet.(Saribekyan dan Margvelashvili,2017). Menurut Arsyad (dalam Baurus,Ulian dan Suratno, 2015:18) Media pembelajaran adalah media yang membawa pesan-pesan atau informasi yang bertujuan instruksional atau mengandung maksud-maksud pengajaran.

Siswa memiliki tingkat kesulitan yang tinggi dalam memahami dan mendeskripsikan cara reproduksi atau siklus hidup jamur. Berdasarkan hal tersebut maka diperlukan suatu solusi yang dapat membantu mahasiswa dan dosen dalam mengatasi keterbatasan objek yang akan diamati dengan penyajian media dalam pembelajaran. multimedia akan merangsang beberapa organ sensorik siswa, sehingga pemahaman siswa terhadap Biologi menjadi lebih sempurna. Siswa yang diajar melalui multimedia memiliki pemahaman yang tinggi tentang konsep biologi protista fungi. Dengan demikian multimedia pembelajaran terbukti menjadi strategi pembelajaran atau pengajaran yang unggul. Multimedia juga dapat digunakan untuk latihan, pemecahan masalah, pemahaman sains, konsep, dan simulasi abstrak dalam sains.

\section{METODE PENELITIAN}

Prosedur Pengembangan Untuk mengembangkan media pembelajaran yang baik dalam arti mampu meningkatkan mutu pembelajaran, diperlukan suatu rancangan yang baik. Dalam penyusunan rancangan, berbagai hal harus diperhitungkan, baik menyangkut materi (content), tampilan dan aspek bahasa serta tujuan yang hendak dicapai. Adapun langkah-langkah pengembangan model DDD-E yaitu decide, design, develop dan evaluate. Prosedur Pengembangan Untuk mengembangkan media pembelajaran yang baik dalam arti mampu meningkatkan mutu pembelajaran, diperlukan suatu rancangan yang baik. Dalam penyusunan rancangan, berbagai hal harus diperhitungkan, baik menyangkut materi (content), tampilan dan aspek bahasa serta tujuan yang hendak dicapai. Pada penelitian ini, metode yang digunakan adalah metode Research and Develomenr (R\&D). Menurut Sugiyono (2015:409) membagi berbagai dalam langkah-langkah penelitian dan pengembangan kesebuah 10 tahap sebagai berikut (1) identifikasi masalah, (2) pengumpulan informasi, (3) Desain Produk, (4) valiadasi desain, (5) perbaikan desain, (6) uji coba produk, (7) revive produk, (8) uji coba pemakaian, (9) revisi produk tahap akhir, dan (10) produksi masal. Berikut pada gambar 1 adalah uraian singkat dari masing-masing tahap 


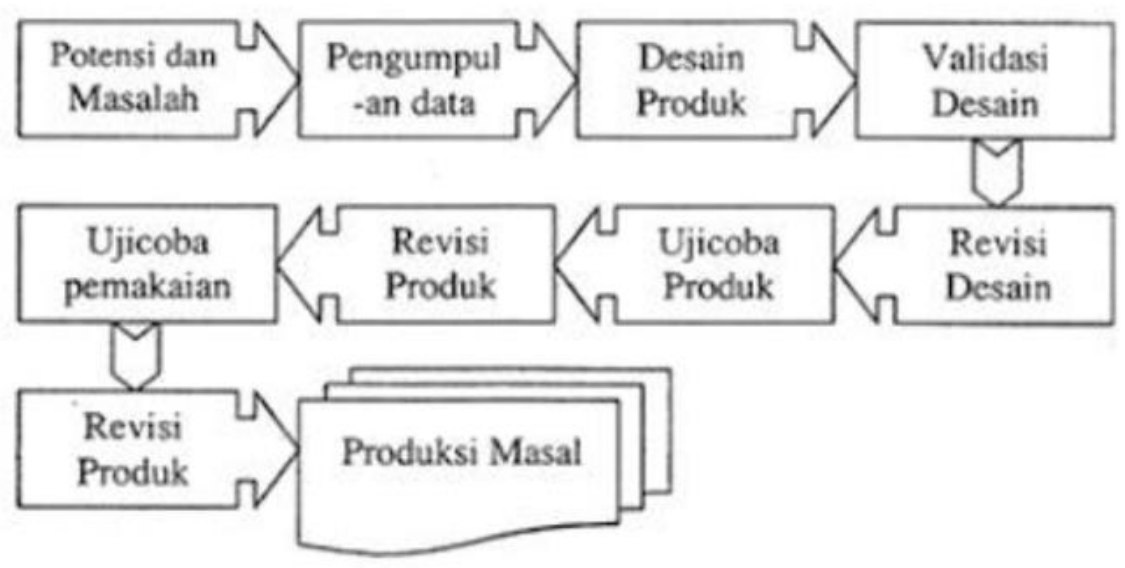

Gambar 1. Desain R \& D (Sugiyono, 2015)

Berdasarkan desain pada gambar 1 , tahap penelitian pada produk pemanfaatan media sosial untuk media pembelajaran adalah berikut ini : Potensi dan masalah Berdasarkan observasi peneliti, permasalahan yang ada pada siswa yakni penggunaan modul yang masih monoton membuat siswa jenuh dan kurang tertarik terhadap pembelajaran yang ada. Dengan demikian, penggunaan media sosial Telegram untuk media pembelajaran diharapkan dapat meningkatkan minat belajar mahasiswa dan mempermudah pemahaman terhadap materi yang disampaikan. Pengumpulan data Data yang didapat oleh penulis berdasarkan observasi dari literatur pelajaran yang ada dengan mengambil referansi yang sudah akurat. Desain produk Produk yang dihasilkan didesain menggunakan Bot Api pada Telegram. Rancangan Penelitian, berikut ini adalah alur dari media pembelajaran yang ditunjukkan pada gambar 2 :

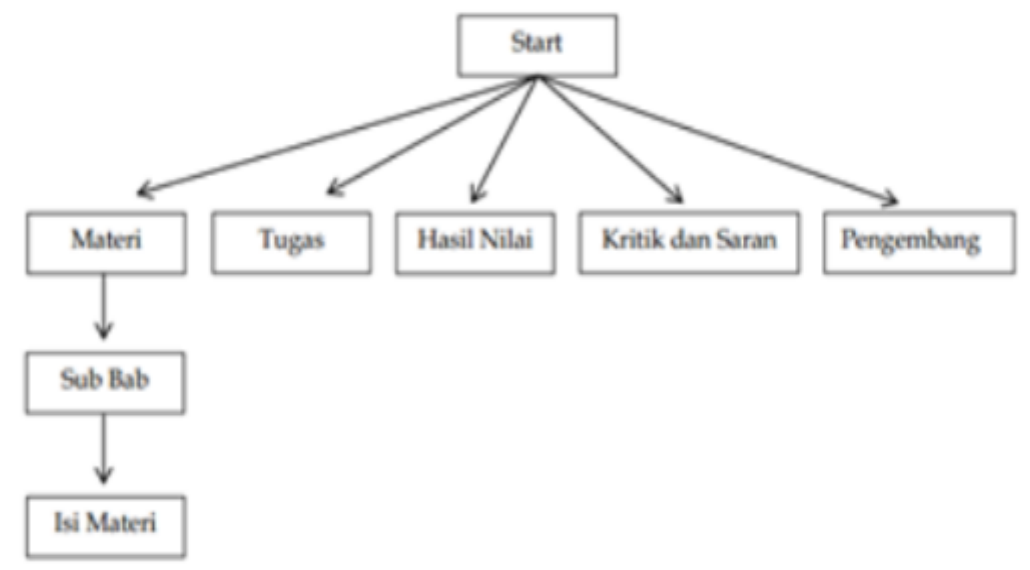

Gambar 2. Alur Media

Teknik Pengumpulan Data Dan Pengembangan Instrument. Instrumen pengumpulan data yang digunakan yaitu lembar validasi untuk ahli media, ahli materi dan respon mahasiswa. Instrumen Angket Validasi Media Media.Instrumen angket validasi media disusun berdasarkan pendapat Walker \& Hess (Arsyad, 2013 : 175-176) mengenai kriteria penilaian media pembelajaran berdasarkan pada kualitas. Instrumen Angket Validasi Materi Instrument angket validasi materi disusun berdasarkan Riset, Teknologi dan Pendidikan Tinggi mengenai kualitas materi pembelajaran. Instrumen Angket Respon Mahasiswa Instrument angket respon mahasiswa disusun berdasarkan model kualitas system dari Delone and Mclean. 
Teknik Analisis Data Analisis data merupakan kegiatan yang dilakukan setelah seluruh sumber data terkumpul. Analisis data digunakan untuk menjawab rumusan masalah yang terdapat dalam penelitian. Penelitian ini menggunakan teknik analisis data kuantitatif karena data yang digunakan berupa angka-angka. Data kuantitatif dari penelitian ini yaitu berupa data skor penilaian validasi media pembelajaran Telegram dari delapan siswa pengguna bot, skor respon dari siswa, dan data respon siswa setelah digunakan media pembelajaran ini. ada data validitas media dan materi ini, teknik analisis datanya menggunakan teknik deskriptif kuantitatif, yaitu dengan memberikan gambaran dari saran yang telah diberikan ahli media dan ahli materi sehingga dapat diketahui kualitas yang terdapat baik pada media maupun materi.

Prosedur Penelitian dan Pengembangan ini dilakukan dengan kerangka berfikir. Penelitian ini menggunakan jenis penelitian Research and Development (penelitian dan pengembangan). Research and Development dapat didefinisikan sebagai metode penelitian yang bertujuan untuk menghasilkan sebuah produk tertentu dan menguji keefektifannya (Sugiyono,2015:407). Pengelompokan yang dilakukan menjadi empat tahap tersebut bertujuan memudahkan dalam proses penelitian dan tidak mengurangi makna dari masing-masing langkah yang sebenarnya. Pengumpulan data dalam penelitian ini dilakukan dengan menggunakan instrumen. Instrumen yang digunakan dalam penelitian ini adalah angket yang diberikan kepada ahli konten/materi, ahli desain, dan siswa yang mempelajari mata pembelajaran protista fungi sebagai respondennya. Berdasarkan instrumen tersebut diperoleh data yang dibutuhkan dalam penelitian dan pengembangan produk. Observasi digunakan untuk melihat kebutuhan yang diperlukan di lapangan dari rumah mematuhi protokol kesehatan dimasa pandemi covid19.

Prosedur Pengembangan Untuk mengembangkan media pembelajaran yang baik dalam arti mampu meningkatkan mutu pembelajaran, diperlukan suatu rancangan yang baik. Dalam penyusunan rancangan, berbagai hal harus diperhitungkan, baik menyangkut materi (content), tampilan dan aspek bahasa serta tujuan yang hendak dicapai. Adapun langkah-langkah pengembangan model DDD-E yaitu decide, design, develop dan evaluate. Prosedur Penelitian dan Pengembangan ini dilakukan dengan kerangka berfikir.

\section{HASIL PENELITIAN DAN PEMBAHASAN}

Hasil penelitiaan menunjukkan bahwa skor validasi terhadap media diperoleh 87,6 \% secara keseluruhan. Dari aspek kualitas dan tujuan diperoleh skor $84 \%$ kategori sangat baik. Pada aspek instruksiona dan teknis diperoleh masing-masing 94\% dan 83,3\%. Hasil Skor validasi media tersebut dapat dilihat pada table 1.

Tabel 1. Skor Validasi Media

\begin{tabular}{lccccc}
\hline No & Perhitungan & \multicolumn{4}{c}{ Aspek } \\
\cline { 3 - 6 } & & Keseluruhan & Kualitas \& Tujuan & Intruksional & Teknis \\
1. & Jumlah Responden & 2 & 2 & 2 & 2 \\
2. & Jumlah Pertanyaan & 13 & 5 & 5 & 3 \\
\hline 3. & Skor Maksimal & 130 & 50 & 50 & 30 \\
$\mathbf{4}$ & Skor yang diperoleh & 114 & 42 & 47 & 25 \\
$\mathbf{5 .}$ & Skor Rata-Rata & 4,38 & 4,2 & 4,7 & 4,1 \\
$\mathbf{6}$ & Presentase & $87,6 \%$ & $84 \%$ & $94 \%$ & $83,3 \%$ \\
\hline
\end{tabular}


Sementara itu untuk skor respon dari mahasiswa yang telah menggunakan produk ini diperoleh skor $90 \%$ untuk aspek keseluruhan. Skor pada aspek kualitas system diperoleh $95 \%$ kategori sangat baik. Pada aspek penggunaan system diperoleh skor $88 \%$, dengan skor maksimal 12,5 dan jumlah responden 8 orang mahasiswa. Untuk lebih lengkapnya dapat dilihat pada table 2.

Tabel 2. Skor Respon Mahasiswa

\begin{tabular}{lccccccc}
\hline No & Perhitungan & \multicolumn{7}{c}{ Aspek } \\
\cline { 3 - 8 } & Keseluruhan & $\begin{array}{c}\text { Kualitas } \\
\text { Sistem }\end{array}$ & $\begin{array}{c}\text { Penggunaan } \\
\text { Sisitem }\end{array}$ & $\begin{array}{c}\text { Kepuadan } \\
\text { Pengguna }\end{array}$ & $\begin{array}{c}\text { Kualitas } \\
\text { Informasi }\end{array}$ & $\begin{array}{c}\text { Manfaat yang } \\
\text { Dirasakan }\end{array}$ \\
1. & Jumlah Responden & 8 & 8 & 8 & 8 & 8 & 8 \\
2. & Jumlah Pertanyaan & 40 & 8 & 5 & 8 & 8 & 10 \\
3. & Skor Maksimal & 100 & 20 & 12,5 & 20 & 20 & 25 \\
4. & Skor yang diperoleh & 90 & 19 & 11 & 17 & 18 & 24 \\
$\mathbf{5 .}$ & Skor Rata-Rata & 0,9 & 0,95 & 0,88 & 0,85 & 0,9 & 0,96 \\
6. & Presentase & $90 \%$ & $95 \%$ & $88 \%$ & $85 \%$ & $90 \%$ & $96 \%$ \\
\hline
\end{tabular}

Gambar menut Bot, kelas pembelajaran dan materi pembelajaran, serta Quiz dapat dilihat pada gambar berikut:

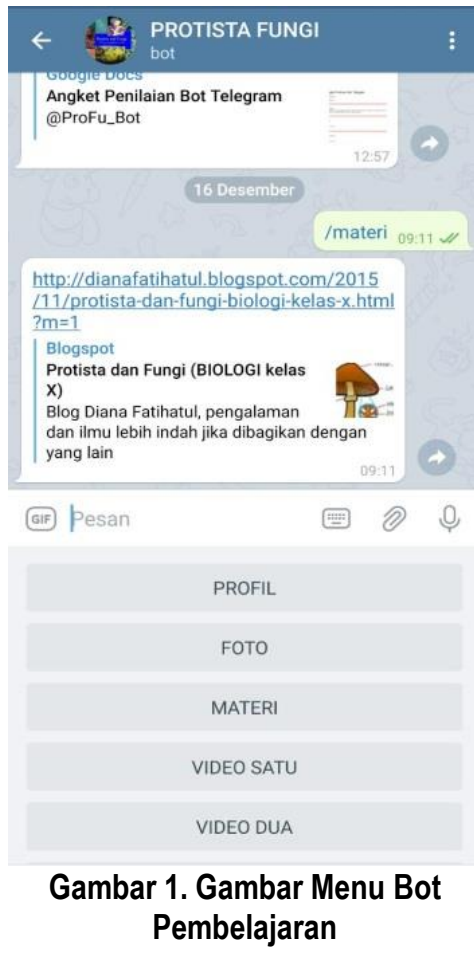

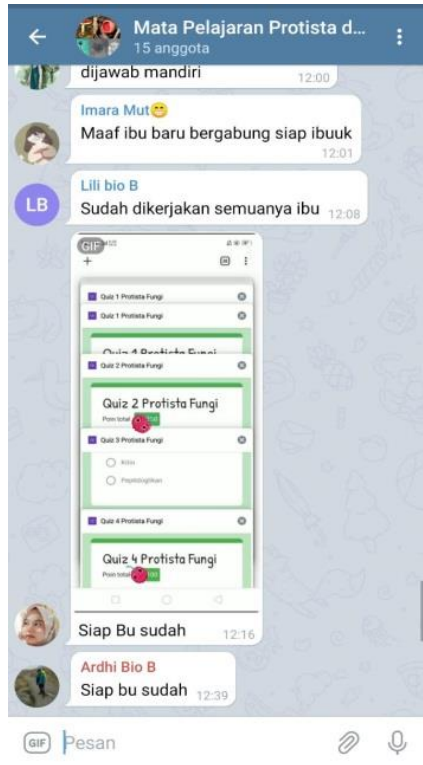

Gambar 2. Kelas Pembelajaran

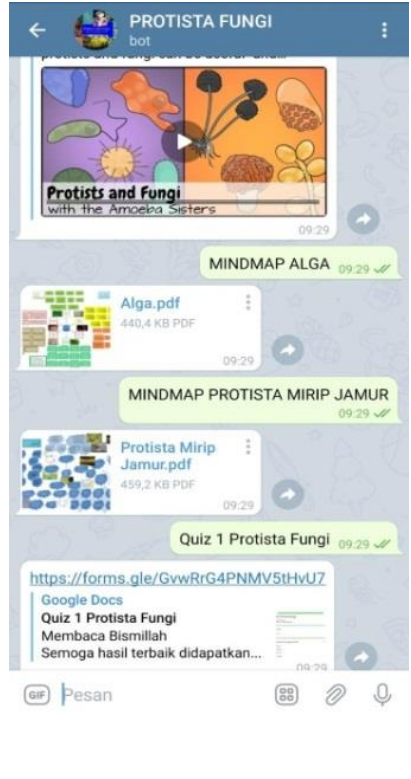

Gambar 3. Materi dan Quiz

Berdasarkan Tabel 1. dan Gambar 1. Dapat dilihat bahwa hasil multimedia interaktif bot telegram Validasi pembelajaran pada materi Protista dan Fungi oleh delapan siswa sebagai pengguna bot ini untuk setiap aspek yang dinilai. Aspek kelayakan media secara keseluruhan meiliki presentase $87,6 \%$. Multimedia pembelajaran interaktif bot telegram protista fungi dikatakan sangat valid karena telah memenuhi keempat aspek yaitu kesesuaian isi, kebahasaan, sesaji dan grafik. Produk yang dihasilkan dalam penelitian ini yaitu media pembelajaran dengan mengembangkan media sosial bot telegram. Media tersebut akan berisi materi tentang biologi protiata fungi berupa gambar, mindmap, ppt dan video. Untuk mengakses mediA ini, pengguna harus menambahkan akun @ProFuBot sebagai teman, setelah itu pengguna dapat berkirim pesan dengan akun @ProFuBot untuk mengakses materi didalamnya dan mengikuti alur menu yang telah disajikan pengajar dalam pembuatan bot. 


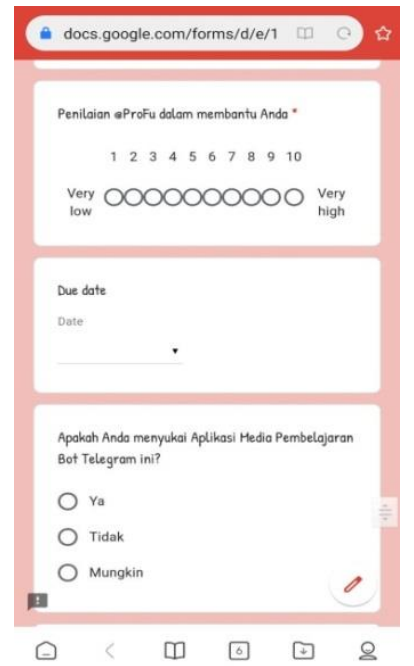

Gambar 4. Angket Penilaian Media Pembelajaran

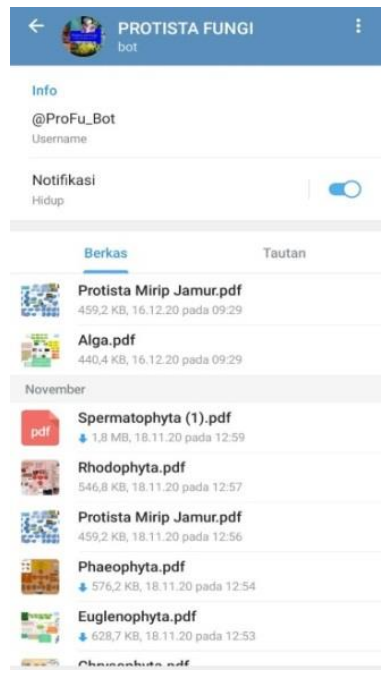

Gambar 5. Gambar Media Pembelajaran ProFuBot

Instrumen validasi media pembelajaran telegramdikembangkan oleh peneliti dengan diadaptasi pada teori walker \& Hess (Arsyad, 2013 : 175-176). Penilaian aspek kelayakan konten diperoleh 80\% dengan kategori valid. Kategori valid diperoleh karena multimedia bot telegram sudah sesuai dengan indikator pembelajaran. Konsep-konsep sulit yang telah divisualisasikan dalam bentuk animasi, animasi dapat bermanfaat untuk mengatasi permasalahan siswa. Hal ini sesuai dengan pendapat (Asyhar, R. 2012.) Bahwa animasi mempunyai kemampuan untuk dapat mengekspos sesuatu yang kompleks atau kompleks untuk dijelaskan, mampu menjelaskan suatu materi yang secara jelas tidak terlihat oleh mata. Animasi memiliki kelebihan sebagai sarana untuk memberikan pemahaman kepada siswa tentang materi yang diberikan dan menarik perhatian siswa serta meningkatkan motivasi.

Hasil validasi multimedia pembelajaran interaktif pada aspek respon mahasiswa secara keseluruhan $90 \%$ dengan kategori sangat valid. Multimedia pembelajaran interaktif memenuhi aspek kebahasaan karena menggunakan norma bahasa Indonesia yang baik dan benar. Serta sudah menggunakan struktur kalimat yang jelas dan menggunakan kosakata yang benar. Salah satu kriteria bahan ajar multimedia adalah narasi atau bahasa harus jelas dan mudah dipahami oleh siswa, penggunaan istilah perlu disesuaikan dengan penggunaan media agar pembelajaran dapat efektif. Semua bahan ajar harus memperhatikan komponen kebahasaan yang sesuai dengan aspek kelayakan bahasa, sehingga keakuratan struktur kalimat dan susunan materi yang sistematis akan memudahkan siswa dalam memahami pembelajaran.

Hal ini membuktikan bahwa media mempunyai peran untuk membantu memudahkan belajar siswa dan membantu kemudahan mengajar ketika menyajikan suatu konsep atau konsep yang abstrak yang akan diwujudkan dalam bentuk konkret atau nyata. Hal ini sejalan dengan (Rusman. 2011) yang menyatakan Penelitian penggunaan multimedia interaktif dalam pembelajaran membuat pesan yang disampaikan dalam materi lebih nyata karena disajikan dalam tampilan polos dan dapat merangsang berbagai indera sehingga ada interaksi antara indera siswa. Pembelajaran dapat berhasil dengan baik jika siswa diajak untuk memanfaatkan semua inderanya. Semakin banyak perangkat sensorik yang digunakan untuk menerima dan mengolah informasi, semakin besar kemungkinan informasi tersebut dipahami dan dipahami serta dapat disimpan dalam memori.

Siswa yang diajar melalui multimedia memiliki pemahaman yang tinggi tentang konsep Biologi. Dengan demikian multimedia terbukti menjadi strategi pembelajaran atau pengajaran yang unggul. 
Multimedia juga dapat digunakan untuk latihan, pemecahan masalah, pemahaman sains, konsep, dan simulasi abstrak dalam sains. Multimedia memperhitungkan gaya belajar siswa yang berbeda. Multimedia mampu membangun pengetahuan siswa secara aktif, bekerja dalam kelompok dan menggunakan multi indera. Multimedia memberikan kesempatan kepada siswa untuk dapat belajar dimanapun dan kapanpun (fleksibilitas) (Satyaprakasha Yaspal, Sudhanshu. 2014)

Hasil validasi multimedia pembelajaran interaktif bot telegram materi biologi protist fungi pada aspek penyajian diperoleh $85 \%$ dengan kategori sangat valid. Multimedia pembelajaran interaktif memenuhi aspek penyajian karena penyajian materi dalam multimedia bersifat berurutan, sudah interaktif. Selain itu multimedia dapat meningkatkan minat dan motivasi siswa dalam belajar serta memiliki informasi yang lengkap. Media interaktif dapat meningkatkan motivasi dan keefektifan hasil belajar bagi penggunanya sesuai kebutuhan siswa beriringan dengan tuntutan kewajiban materi yang wajib di berikan oleh pengajar.

\section{SIMPULAN}

Berdasarkan hasil analisis data yang didapat dari penilaian dengan demikian maka media pembelajaran ini dinyatakan valid untuk digunakan sebagai penunjang pembelajaran. Dari hasil analisis terhadap respon siswa dapat disimpulkan bahwa responden mengatakan Sangat Setuju jika media telegram digunakan sebagai penunjang pembelajaran. Penilaian aspek kelayakan konten diperoleh $80 \%$ dengan kategori valid. Kategori valid diperoleh karena multimedia bot telegram sudah sesuai dengan indikator pembelajaran. Konsep-konsep sulit yang telah divisualisasikan dalam bentuk animasi, animasi dapat bermanfaat untuk mengatasi permasalahan siswa. Aspek kelayakan media secara keseluruhan meiliki presentase $87,6 \%$. Multimedia pembelajaran interaktif bot telegram protista fungi dikatakan sangat valid karena telah memenuhi keempat aspek yaitu kesesuaian isi, kebahasaan, sesaji dan grafik.

\section{UCAPAN TERIMA KASIH}

Terimakasih disampaikan kepada semua pihak dan para siswa serta rekan-rekan yang telah membantu peneliti hingga dapat menyelesaikan penelitian tentang multimedia pembelajaran berbasis bot telegram ini pada materi biologi protiata fungi. Semoga kedepannya peneliti dapat membuat penelitian lebih baik lagi.

\section{RUJUKAN}

Arsyad Azhar. 2013. Media Pembelajaran. Jakarta : Pt Raja Grafindo Persada Arsyad, Azhar. 2015. Media Pembelajaran. Jakarta: PT RajaGrafindo Persada Asyhar, Rayandra. 2012. Kreatif Mengembangkan Media Pembelajaran. Jakarta: Referensi Jakarta.

Rusman, dkk (2011) Pembelajaran Berbasis Teknologi Informasi dan Komunikasi : Mengembangkan Profesionalisme Guru. Jakarta:Rajawali Pers. PT. Raja Grafindo Persada

Saribekyan, Hayk dan Margvelashvili, Akaki. 2017. Security Analysis of Telegram,

Satyaprakasha. 2014. "Research Studies of Effect of Cooperative Learning on Children's Learning Preference". International Journal of Informative and Futuristic Reseacrh. Vol. 2. Issue. 4. Hal. 11001106.

Sugiyono. 2010. Metode Penelitian Kualitatif, Kuantitatif, dan R\&D. Bandung: Alfabeta.

Tamimuddin, Muhammad. 2007. Mengenal Mobile Learning. LIMAS edisi 18. 
BIODIK: Jurnal IImiah Pendidikan Biologi

Vol. 07, No. 04 (2021), Hal. $61-69$

Wibawa, Setya Chendra; Harimurti, Rina; Anistyasari, Yeni dan Sumbawati, Meini Sondang. 2017. The Design And Implementation Of An Educational Multimedia Interactive Operation System Using Lectora Inspire.

Widoyoko, Eko Putro. 2011. Teknik Penyusunan Instrumen Penelitian. Yogyakarta: Pustaka Pelajar. 